
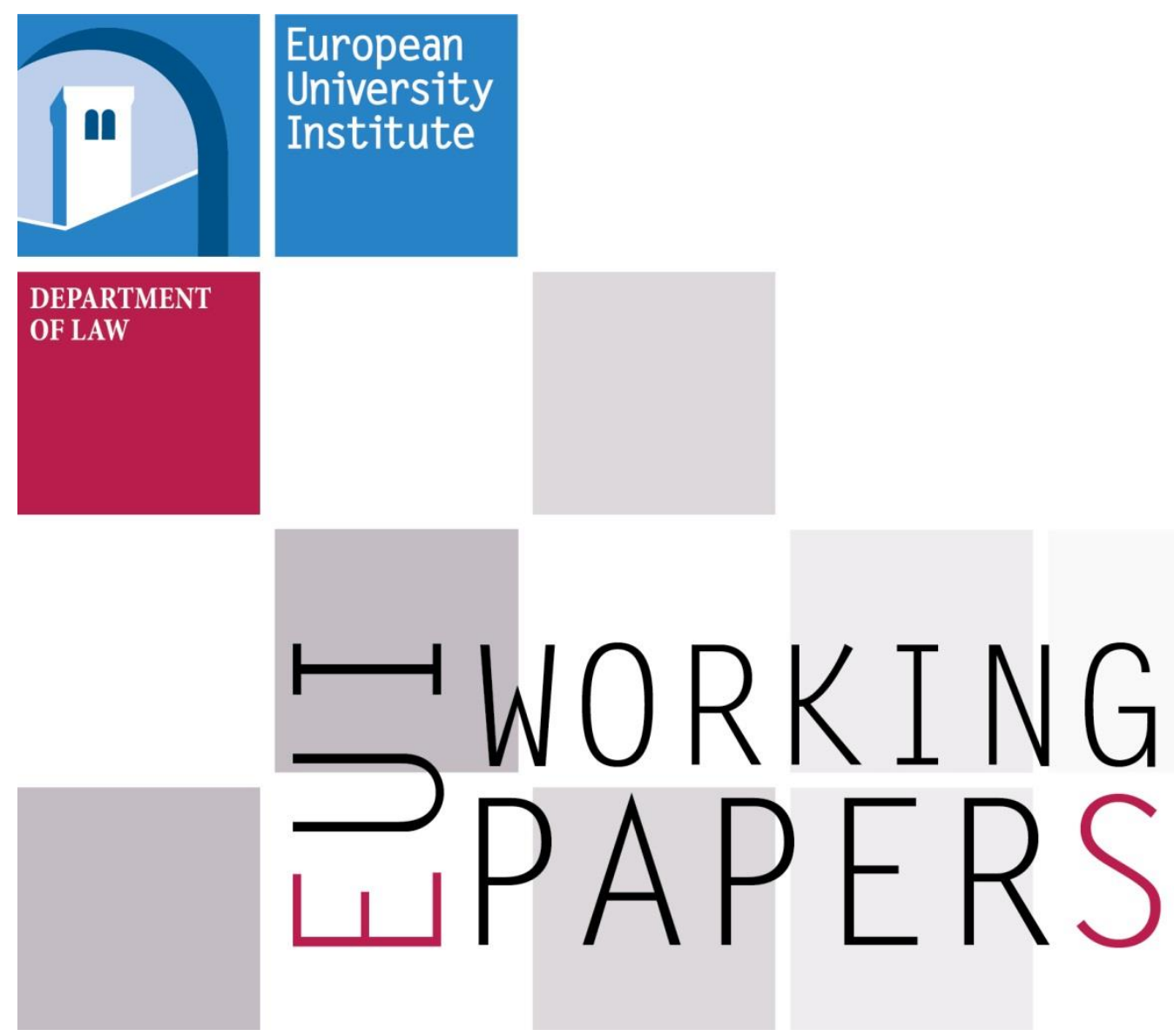

LAW 2015/18

Department of Law

\title{
Umbrella Pricing and Cartel Damages under EU Competition Law
}

Jens-Uwe Franck 

European University Institute

Department of Law

Umbrella Pricing and Cartel Damages

UNDER EU COMPETITION LAW

Jens-Uwe Franck

EUI Working Paper LAW 2015/18 
This text may be downloaded for personal research purposes only. Any additional reproduction for other purposes, whether in hard copy or electronically, requires the consent of the author(s), editor(s). If cited or quoted, reference should be made to the full name of the author(s), editor(s), the title, the working paper or other series, the year, and the publisher.

ISSN 1725-6739

(C) Jens-Uwe Franck, 2015

Printed in Italy

European University Institute

Badia Fiesolana

I-50014 San Domenico di Fiesole (FI)

Italy

www.eui.eu

cadmus.eui.eu 
Author's contact details

\section{Jens-Uwe Franck}

Department of Law

University of Mannheim

e-mail:jfranck@mail.uni-mannheim.de 


\begin{abstract}
This article explores whether cartelists should be liable for losses resulting from umbrella pricing, thereby critically evaluating the ECJ's judgment in "Kone". Since the EU legislature did not resolve the question of liability for umbrella pricing, it has to be evaluated in accordance with national law, which must however comply with the principles of equivalence and effectiveness pursuant to Article 4(3) TEU. Therefore and in accordance with the Court's judgment in "Courage", the decisive criterion should be the effect a cartelist's liability for umbrella pricing would have on effective and efficient enforcement of competition law. An analysis based on the standard model of optimal sanctioning reveals the ambivalent effect of such a liability. Thus, in view of opposing risks of systematic overand under-deterrence and in accordance with the principle of institutional balance, the Court has to leave the EU legislature and the national legislatures, respectively, with the discretion not to provide for compensation in the case of umbrella effects.
\end{abstract}

\title{
Keywords
}

Umbrella pricing, competition law damages, principle of effectiveness, institutional balance, reasonable foreseeability. 


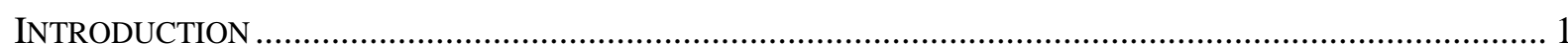

UMBRELLA PRICING AS A LEGAL WAY TO EXTRACT MONOPOLY RENTS ............................................ 2

THE AMBIVALENCE ABOUT THE DETERRENT EFFECT OF A LIABILITY FOR UMBRELLA PRICING .............. 4

The standard model of optimal sanctions: liability for umbrella effects as a "second-best" solution.................. 4

Risks of systematic over-deterrence due to cartel members' liability for umbrella pricing ........................................ 4

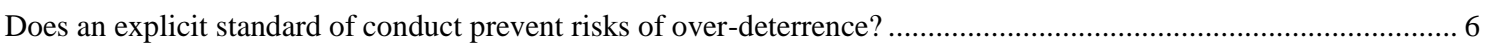

Risk of systematic under-deterrence due to deadweight loss triggered by umbrella pricing....................................... 8

Weighing up the opposing risks of malfunction and their controllability ......................................................... 9

Burdening the courts with (too) complex calculations and unsubstantiated claims? ................................ 10

On the weakness of the compensatory function as a rationale governing damages liability ......................... 11

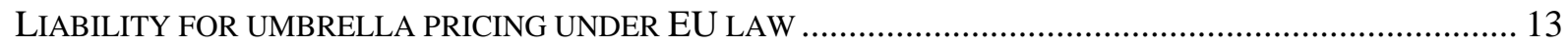

Allocation of powers under EU law and the principle of institutional balance ......................................... 13

Liability for umbrella effects as a discretionary decision of the EU legislature and, on a subsidiary basis,

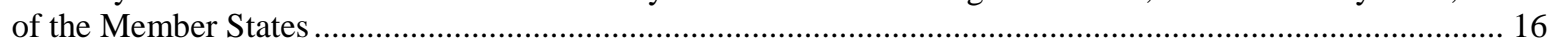

The principle of effectiveness does not require liability for umbrella effects ..................................................... 17

Liability for umbrella pricing and incentives to apply for leniency .............................................................. 18

Market definition does not limit liability for losses resulting from umbrella pricing............................................ 19

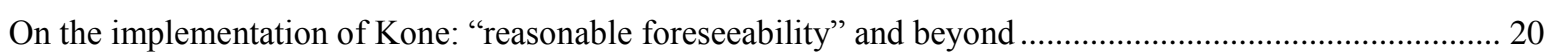

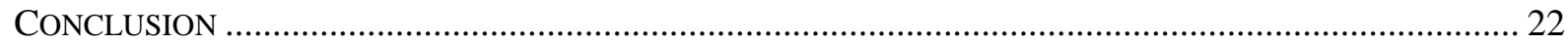





\section{Introduction*}

Any undertaking violating EU competition law may be liable for losses resulting from umbrella pricing. This is what the European Court of Justice recently held in Kone. ${ }^{1}$ The image of "umbrella pricing" is used to sketch a scenario where an undertaking benefits from a larger price setting freedom due to the fact that its competitors form a cartel. If a firm observes that its competitors are reducing their output and increasing their prices in a coordinated manner, it can basically choose between two strategies which may maximise profit. It can either assume the role of the maverick, by leaving its price below competition and increasing its output, or it can silently benefit from the cartel by adapting its price to that of the cartel and reducing its output accordingly. Which option appears to be preferable depends on the respective market conditions. The larger the market share of the cartelists, the higher the product homogeneity and the lower the elasticity of supply of the undertaking not party to the cartel, the more likely a firm will tend to choose the second strategy. ${ }^{2}$ Since the undertakings which are not party to the cartel benefit, in this situation, from "being under the umbrella of the cartel", this conduct is commonly referred to as umbrella pricing. ${ }^{3}$

Yet it is important to appreciate that this image of an "umbrella" being opened by the cartelists derives from a one-sided perspective. In fact it neglects the interdependence between the price which the cartel can enforce and the pricing of their competitors who are not party to the cartel. To the extent that the latter silently align their prices, they, in turn, enable the cartel members to enforce a higher cartel price on the market. Thus, the cartel not only increases the price setting freedom for the firms not party to the cartel, but by following suit, the latter broaden the scope to set prices for the cartel in the same way.

The dispute about the legal analysis of umbrella effects in Kone arose in the aftermath of the detection of the elevators and escalators cartel. In February 2007, the European Commission imposed on Kone, Otis and Schindler a fine totalling EUR 992 million for participating in cartels involving activities in Belgium, Germany, Luxembourg and the Netherlands. In October 2008, the Austrian Oberste Gerichtshof confirmed an order of the Kartellgericht which had imposed fines inter alia on Kone, Otis and Schindler. Subsequently, ÖBB-Infrastruktur, a subsidiary of the State-owned Austrian railways, sued the three aforementioned firms as well as ThyssenKrupp (that had successfully applied for leniency), and claimed compensation for cartel damage including those resulting from umbrella pricing. ÖBB-Infrastruktur alleged that it had procured goods and services from a provider who did not, in fact, participate in the cartel but who had increased its prices due to the cartel. This gave rise to additional costs for ÖBB-Infrastruktur amounting to approximately EUR 1.8 million.

The Oberste Gerichtshof concluded that under Austrian law ÖBB-Infrastruktur was not entitled to a claim for damages in this respect. The court substantiated this result with two arguments. Firstly, it argued that the pricing of the firm not party to the cartel had to be considered an independent decision based on its own business considerations, this decision had therefore not been foreseeable for cartelists

\footnotetext{
* I am grateful for the comments, questions and suggestions from Thomas Ackermann, Andreas Hahne, Alexander Hellgardt, Giorgio Monti, Heike Schweitzer, Alexander Seitz and Christoph Weber. Any remaining errors remain mine.

${ }^{1}$ ECJ, 5.6.2014, Case C-557/12 Kone AG and others v ÖBB-Infrastruktur AG.

2 On the economics of umbrella pricing see RD Blair and VG Maurer, "Umbrella Pricing and Antitrust Standing: An Economic Analysis" (1982) Utah Law Review 763, 779-785; RD Blair and CP Durrance, "Umbrella Pricing: Antitrust Injury and Standing", in ABA Section of Antitrust Law, Issues in Competition Law and Policy, vol 2 (New York and Oxford, Oxford University Press, 2008), 2349, 2350-2355; R Inderst, F Maier-Rigaud and U Schwalbe, "Umbrella effects" (2014) 10 Journal of Competition Law and Economics 739-763.

${ }^{3}$ See, for example, PE Areeda, H Hovenkamp, RD Blair and CP Durrance, Antitrust Law, Vol II (New York, Wolters Kluwer, 3rd edn, 2007), § 347, 198.
} 
and thus, no adequate causal link may be established. ${ }^{4}$ Secondly, the court also denied a link of unlawfulness between the competition law infringement and the loss caused by umbrella pricing. As the cartel members seek to injure only their own customers by artificially high prices, umbrella pricing had to be considered a mere side-effect which does not fall within the protective purpose of the prohibition of cartels. ${ }^{5}$ However, since the Oberste Gerichtshof was not sure whether, in compliance with EU law, it was allowed to rule out compensation for loss resulting from umbrella pricing, it referred the question to the ECJ.

The phenomenon of umbrella pricing and whether it should trigger a liability for damages under EU law will be looked into in three main sections. First, it is necessary to consolidate the starting point (section B). Even if undertakings not party to a cartel deliberately act in (silent) accordance with the collusive strategy of their competitors who are involved in the cartel, their conduct does not violate the ban on anti-competitive coordination pursuant to Article 101 TFEU. Therefore, in the case of "umbrella transactions", customers cannot claim damages from undertakings not party to the cartel.

For the question of whether cartel members should be liable for losses resulting from umbrella pricing, an insight into the ambivalent sanctioning effect of such liability is of fundamental importance, which will then be set out under section C. On the basis of the standard model of optimal sanctions it can be shown that damages for losses resulting from umbrella pricing create risks of systematic overdeterrence and can therefore only be recommended as a "second-best" solution at most. It follows from this that the decision on the eligibility of umbrella pricing losses for compensation largely depends on a balancing exercise between opposing risks of malfunction and their controllability.

We will look into the conclusions that can be drawn from this from an EU law perspective under section D. The EU legislature has the authority to determine the scope of cartel damages pursuant to Article 103 TFEU. The principle of institutional balance thus prevents the ECJ from deciding on damages for losses resulting from umbrella pricing by relying directly on Article 101 TFEU. Since the legislature passing secondary legislation did not resolve the issue, the latter has to be evaluated in accordance with national law, which must however comply with the principles of equivalence and effectiveness (Article 4(3) TEU). Contrary to the Court's judgement in Kone, the decision on whether to grant or prevent claims for compensation for umbrella pricing losses is to be made at the discretion of the legislature passing secondary EU legislation and (on a subsidiary basis) of national law.

In conclusion, the position of the ECJ as to the conditions under which losses resulting from umbrella pricing are not to be deemed eligible for compensation will be considered and it will be discussed how these requirements could be integrated into national liability law.

\section{Umbrella pricing as a legal way to extract monopoly rents}

Undertakings which are not party to a cartel do not violate the prohibition of anti-competitive coordination if they tacitly adapt themselves to the collusive conduct of their competitors who form a cartel. This point of view conforms to the general assessment pursuant to which tacit collusion as such may not be considered a breach of Article 101(1) TFEU. This assessment is reflected in the case-law on "concerted practices" in which the ECJ gives undertakings some leeway "to adapt themselves

\footnotetext{
${ }^{4}$ Oberster Gerichtshof, 17.10.2012, 7 Ob 48/12b, at para 5: "Nach österreichischem Recht ist der Kausalzusammenhang wegen des Dazwischentretens einer eigenständigen unternehmerischen Entscheidung des Kartellaußenseiters, die eine Vielzahl von Gründen haben kann und damit für die Kartellanten nicht absehbar ist, unterbrochen.”

5 Ibid:

bid: "Nach österreichischem Recht ist beim Umbrella-Pricing auch der Rechtswidrigkeitszusammenhang zu verneinen. Die rechtswidrigen Handlungen der Kartellanten zielen auf eine Schädigung jener ab, die ihre Produkte zu den von ihnen künstlich hoch gehaltenen Preisen erwerben. Der Schaden durch Umbrella-Pricing tritt nur infolge einer Seitenwirkung wegen der selbständigen, aus eigenen unternehmerischen Erwägungen des Kartellaußenseiters motivierten Entscheidung ein und ist als mittelbarer Schaden nicht zu ersetzen.“
} 
intelligently to the existing and anticipated conduct of their competitors". ${ }^{6}$ The Court requires an element of mutual concertation beyond mere market conduct, typically an exchange of information relevant for pricing. Moreover, the case-law on "collective dominance" sheds light on the fact that tacit collusion as such is not covered by Article 101(1) TFEU. Accordingly, one decision on merger control states:

Unless they can form a shared tacit understanding of the terms of the coordination, competitors might resort to practices that are prohibited by Article 81 EC [now Article 101 TFEU] in order to be able to adopt a common policy on the market. ${ }^{7}$

A deadweight loss may follow from tacitly collusive leader-follower conduct - as in the case of umbrella pricing - in a comparable way ${ }^{8}$ as from explicitly coordinated conduct. The fact that tacit collusion, despite such anti-competitive effect, is not prohibited as such is essentially based on two intricacies: ${ }^{9}$ firstly, in many cases, it is difficult to distinguish tacit collusion from functioning oligopolistic competition in a sufficiently clear manner. Creating false positives, however, would seem to be rather risky in the context of the application of the ban on cartels, for this directly results in an interference with the freedom to set prices, possibly entailing far-reaching and counter-productive consequences for the freedom of competition. Secondly, and more fundamentally, it should be borne in mind that it is not sufficient for the implementation of the cartel prohibition to show that market equilibrium has been reached as a result of a collusive strategy, as the ban on cartels does not address the fact that undertakings charge collusive, i.e. supra-competitive prices. Rather, it prohibits the coordination of market conduct. This regulatory technique precludes a disproportionate restriction of the freedom of competition and prevents the cartel prohibition from mutating into a tool of permanent price control.

As a consequence, firms which are not party to a cartel are under no obligation, in view of competitors who form a cartel, to keep their prices at a constant level or below the level of the cartel members and to increase their output quantities. The fact that undertakings which are not party to a cartel do not infringe competition law through umbrella pricing does not, however, change the fact that the resulting deadweight loss should be prevented. Prohibiting umbrella pricing is quite simply not a potentially suitable tool for this purpose. Rather, one should seek to provide cartel members with sufficient incentives to refrain from competition law violations. With this in mind, the question arises whether cartelists should be liable for losses resulting from umbrella pricing.

\footnotetext{
${ }^{6}$ ECJ, 16.12.1975, Joined cases 40 to 48, 50, 54 to 56, 111, 113 and 114/73 Suiker Unie and others v Commission [1975] ECR 1663 para 173/174; 14.7.1981, Case 172/80 Züchner v Bayerische Volksbank [1981] ECR 2021 para 14; 8.7.1999, Case C-199/92 P, Hüls v Commission [1999] ECR I-4336, para 160.

${ }^{7}$ ECJ, 10.7.2008, Case C-413/06 P Bertelsmann and Sony Corporation of America v Impala [2008] ECR I-4951, para 123.

${ }^{8}$ Explicit communication may facilitate an agreement of undertakings on a particular (collusive) equilibrium, MA Fonseca and H-T Norman, "Explicit vs. tacit collusion - The impact of communication in oligopoly experiments" (2012) 56 European Economic Review 1759, 1760.

${ }^{9}$ On this point, see P Andreoli-Versbach and J-U Franck, "Actions Speak Louder than Words: Econometric Evidence to Target Tacit Collusion in Oligopolistic Markets", forthcoming Journal of Competition Law and Economics, sub (1). The question of the extent to which competition law can and should directly address tacit collusion as illegal coordination has long been the subject of controversy. Fundamentally in favour of the restrictive position DF Turner, "The Definition of Agreement under the Sherman Act: Conscious Parallelism and Refusals to Deal" (1962) 75 Harvard Law Review 655, 669-71. In contrast, for an extensive coverage also of deliberate parallel conduct RA Posner, "Oligopoly and the Antitrust Laws: A Suggested Approach" (1968/69) 21 Stanford Law Review 1562-1606. From more recent literature, see for example L Kaplow, "An Economic Approach to Price Fixing" (2011) 77 Antitrust Law Journal, 343-449 and "On the Meaning of Horizontal Agreements in Competition Law” (2011) 99 California Law Review, 683-818.
} 


\section{The ambivalence about the deterrent effect of a liability for umbrella pricing}

In its landmark decision in Courage, the ECJ established liability for cartel damages as a mechanism for the effective enforcement of EU competition law:

The full effectiveness of Article 85 of the Treaty [now Article 101 TFEU] [...] would be put at risk if it were not open to any individual to claim damages for loss caused to him by a contract or by conduct liable to restrict or distort competition. Indeed, the existence of such a right strengthens the working of the Community competition rules and discourages agreements or practices, which are frequently covert, which are liable to restrict or distort competition. ${ }^{10}$

Thus, the question arises whether the objective of the effective enforcement of Article 101 TFEU requires cartelists' liability for umbrella effects.

\section{The standard model of optimal sanctions: liability for umbrella effects as a "second-best" solution}

Risks of systematic over-deterrence due to cartel members' liability for umbrella pricing

The basic idea of liability as a sanctioning mechanism resides in the fact that a firm that has to expect to have to make good losses caused by an infringement of competition law will adjust its conduct accordingly. In compliance with the standard model for efficient sanctions, the expectation value of the sanction determines its preventive effect. ${ }^{11}$ The expectation value of liability for damages depends essentially on two factors: the amount of compensation which is looming, on the one hand, and the likelihood of the aggrieved parties to enforce their claims, on the other. The latter depends again, in particular, on the likelihood that a violation of rights which gives rise to liability is discovered in the first place. The question of whether or not losses resulting from umbrella pricing is eligible for compensation affects the first factor and thereby adjusts the deterrent effect of the liability for damages.

For an optimal deterrence according to the standard model, (potential) wrongdoers should as a starting point have to make good all individual disadvantages resulting from an infringement of competition law in which a deadweight loss becomes manifest. This includes all individual disadvantages which are not the expression of a mere redistribution of welfare among market participants. In addition, such individual disadvantages should also be compensated as loss in which a cartel-related redistribution in favour of the party infringing competition law becomes manifest. Since there seems to be a consensus on the latter point, ${ }^{12}$ the dispute as to whether the optimal sanction should be calculated on the basis of the damage caused (harm based) or of the profit made by the cartel (gain based) ultimately only concerns the question of whether benefits which are based on efficiency gains should also be absorbed from those who infringe competition law, or whether incentives for an "efficient breach" should be

${ }^{10}$ ECJ, 20.9.2001, Case C-453/99 Courage v Crehan [2001] ECR I-6323, paras 26-7.

${ }^{11}$ GS Becker, "Crime and Punishment: An Economic Approach" (1968) 76 Journal of Political Economy 169 (1968) with regard to the "sanction effect" of criminal law, thereafter adopted for assessing the enforcement of competition law in particular by RA Posner and FH Easterbrook, Antitrust Cases, Economic Notes and Other Materials (St. Paul, Minn., West, 2nd edn, 1981), 550; WM Landes, "Optimal Sanctions for Antitrust Violations" (1983) 50 University of Chicago Law Review, 6523 and W Breit and KG Elzinga, "Private Antitrust Enforcement: The New Learning" (1985) 28 Journal of Law and Economics 405.

${ }^{12}$ With regard to liability for damages for violations of competition law Posner and Easterbrook, supra n 11, 550; RA Posner, Economic Analysis of Law (9th ed 2014), §10.14, 394-6; Landes, supra n 11, 656; Breit and Elzinga, supra $\mathrm{n} 11$, 410-412; WH Page, "The Scope of Liability for Antitrust Violations" (1985) 37 Stanford Law Review 1445, 1455; HP Logemann, Der kartellrechtliche Schadensersatz (Berlin, Duncker \& Humblot, 2009), 417. 
left. ${ }^{13}$ However, this may remain undecided in the context of the assessment of loss resulting from umbrella pricing. Yet individual losses which result from a mere redistribution among market participants who are not involved in a violation of competition law should, however, ideally not be deemed eligible for compensation.

If one looks at umbrella transactions against this background, it is immediately evident that neither a deadweight loss nor a transfer to cartel members becomes manifest in the loss resulting from umbrella pricing, for the profit that corresponds to the loss resulting from umbrella pricing remains with the undertakings which are not party to the cartel. Thus, umbrella pricing leads to a windfall profit in their favour. The corresponding losses on the part of their buyers represent indeed mere redistributions among market participants who are not responsible for the violation of competition law. Therefore, in an ideal world of deterrence through liability, losses resulting from umbrella pricing should not have to be compensated. If cartel members are held liable for in this case, this entails risks of systematic over-deterrence. $^{14}$

This insight induced, for example, the U.S. Court of Appeals for the Third Circuit to dismiss claims for damages due to umbrella pricing. ${ }^{15}$ In a landmark decision, the Court stressed the fact that benefits arising from an umbrella transaction caused by a cartel do not flow to the cartel members but to the undertakings not party to the cartel. ${ }^{16}$ The Court then returned to this point again at the end of its judgment by observing that imposing liability on cartel members for the fact that a higher price has established itself in the entire market would go far beyond the amount of what they made as profit in contravention of competition law and could thereby result in ruinous liability for damages. ${ }^{17}$ In the Court's view, this contradicted the intentions of the legislature who, with the liability for treble damages, while intending to have an effective mechanism for enforcing cartel prohibition, had not wanted to create a punitive provision:

Notwithstanding the seriousness of the per se violation present in this case, the judiciary should not be hasty to allow the treble damage action to become so destructive a force, when Congress intended

${ }^{13}$ For the former position, see, for example, WPJ Wils, "Optimal Antitrust Fines: Theory and Practice" (2006) World Competition 183, 191-193, for the latter, see, for example, Landes supra $\mathrm{n}$ 11, 652.

${ }^{14}$ In the light of these risks, amongst others, H Hovenkamp, Federal Antitrust Policy (St. Paul, Minn, Thomson Reuters, 4th edn 2011), 683, pleads against umbrella plaintiffs being entitled to a claim.

15 The U.S. Supreme Court has not positioned itself on the question of liability due to loss resulting from umbrella pricing to date. The appellate courts of two circuits have affirmed standing and proximate causation in favour of the transaction partners of undertakings not party to a cartel: U.S. Court of Appeals, Fifth Circuit, 17.8.1979, In re Beef Industry Antitrust Litigation, 600 F.2d 1148, 1166, fn. 24; U.S. Court of Appeals, Seventh Circuit, 24.11.2003, United States Gypsum Co. v. Indiana Gas Co., Inc., 350 F.3d 623, 627-8. Numerous District Courts have argued in favour of or at least not excluded damages due to umbrella transactions, see for example U.S. District Court, N.D. California, 1.12.2009, In re Online DVD Rental Antitrust Litigation, No. M 09-2029 PJH, 2009 U.S. Dist. LEXIS 10: “[...] the court is not persuaded that there is a categorical bar precluding the umbrella liability theory [in a direct purchaser case]". For an overview of the case-law, see EL Cramer and DC Simons, "Parties entitled to pursue a claim", in AA Foer and R Stutz (eds), Private Enforcement of Antitrust Law in the United States (Cheltenham and Northhampton, Mass, Edward Elgar, 2012), 64, 76; Areeda, Hovenkamp, Blair and Durrance, supra n 3, § 347, 199-200; PE Areeda and H Hovenkamp, Antitrust Law, 2013 Supplement (New York, Wolters Kluwer, 2013), § 347, 168-9.

${ }^{16}$ U.S. Court of Appeals, Third Circuit, 26.3.1979, Mid-West Paper Products Co. v. Continental Group, 596 F.2d 573, 583: "The defendants secured no illegal benefit at Murray's expense; their tainted gains were reaped from those firms to which the actually sold their products; and Murray's added costs, if any, were pocketed by defendants' competitors [...].” This argument was adopted by the U.S. District Court, N.D. Illinois, E.D., 4.12.1980, In re Folding Carton Antitrust Litigation, 88 F.R.D. 211, 220.

${ }^{17}$ U.S. Court of Appeals, Third Circuit, 26.3.1979, Mid-West Paper Products Co. v. Continental Group, 596 F.2d 573, 586: “Allowing recovery for injuries whose causal link to defendants' activities is as tenuous as it is here could subject antitrust violators to potentially ruinous liabilities, well in excess of their illegally-earned profits, because under the theory propounded by Murray, price fixers would be held accountable for higher prices that arguably ensued in the entire industry." 
only that it be used as a weapon to enforce antitrust laws. In this regard, it should be noted that Congress has enacted relatively stiff criminal penalties to punish those who flout the antitrust laws, that the Supreme Court has been especially reticent in sanctioning multiple treble damage recoveries for the same injury, and that other courts have been wary of permitting 'overkill' recoveries, whose punitive impact may unduly cripple a defendant and lead to an overall deleterious effect upon competition. 18

Thus, the Court held that umbrella losses should not to be compensated due to their potentially excessive sanction effect. However, as will be established hereinafter, one should not stop at this finding of a risk of over-deterrence: given the opposing risks of systematic under-deterrence due to an extra deadweight loss caused by umbrella pricing, which cannot be realised in practice, it may nonetheless be opportune to force cartel members to make good any losses resulting from umbrella pricing. Before this aspect is examined in more detail, we must address another objection: does the risk of over-deterrence not already disappear due to the fact that market participants are provided with an explicit standard of conduct through competition law rules?

\section{Does an explicit standard of conduct prevent risks of over-deterrence?}

In Kone, the Court refrained from discussing the risks of an excessive deterrent effect due to a liability for umbrella pricing. In her Opinion, Advocate General Kokott addressed the objection that damages in the case of umbrella pricing did go beyond requiring the disgorging of cartel profits (and thus, leading to compensation for losses which resulted from a mere redistribution among innocent parties), without, however, linking this to the objection - which she addressed elsewhere - that the liability could have an excessive effect. Advocate General Kokott rejected the first objection by invoking the compensatory function of liability: it was irrelevant for the scope of liability whether illegitimate profits were absorbed at the same time by making good damages, because the point of liability was primarily to compensate for losses caused by a cartel. ${ }^{19}$ If, at this point, the Advocate General thereby avoids the argument of (potentially) excessive deterrence, she describes elsewhere the objection that liability risks could lead to an unwanted restriction of the level of activity on the market as "very strange" and justifies this position as follows:

It is sufficient to point out in this regard that the model for trading on the internal market should come in the form of undertakings that comply with the competition rules, not those that seek to engage in illegal practices there at the expense of others. Should the recognition of an obligation on cartel members to pay compensation for umbrella pricing have the effect of keeping black sheep away from the market, this would hardly be detrimental to competition. 20

Advocate General Kokott thereby essentially denies the risks of over-deterrence with the consideration that undertakings are obliged to comply with competition law and could thereby avoid any liability. It is correct in this respect that, for a wrongdoer who is deliberately acting in contravention of competition law, any precaution costs which are provoked by the threat of sanctions extend only to refraining from infringing the law. His efforts to avoid infringing competition law then are equivalent only to the expected value of the missed opportunity for proceeds resulting from the illegal conduct. If one assumes that infringements of competition law are socially undesirable, then the wrongdoer who refrains from infringing competition law can avoid any sanction with costs that amount to zero from a

\footnotetext{
${ }^{18}$ U.S. Court of Appeals, Third Circuit, 26.3.1979, Mid-West Paper Products Co. v. Continental Group, 596 F.2d 573, 5867.

19 Advocate General Kokott, 30.1.2014, Case C-557/12, Kone AG and others, paras 76-78. See also A Fuchs, "Unter dem Schirm und im Schatten des Kartells", in W Büscher et al (eds), Festschrift für Joachim Bornkamm (CH Beck, München, 2014), 159, 166. On compensation as a function of damages and as an argument for making good losses resulting from umbrella pricing, see infra Section C.3.

${ }^{20}$ Ibid, para 68.
} 
social point of view or that are even negative, as the case may be, if one bears in mind that the expenses which go along with a competition law violation are being saved. Thus, if one does not want to leave the door open for an "efficient breach", ${ }^{21}$ it does seem that there is actually no risk that socially desirable market activities will cease as a result of an over-deterrent threat of liability (as measured by the standard model of optimal sanctioning).

When looking more closely, it becomes evident, however, that this analysis only applies under strict conditions. Firstly, it should be borne in mind that undertakings cannot always accurately anticipate the dividing line between what is allowed and what is not allowed. The ban on hardcore cartels, that is, in particular, horizontal agreements on price, quantities etc. may be obvious. Aside from this, however, the benchmark for conduct in compliance with competition law is not always crystal clear. In quite a few situations, pro- and anti-competitive effects, as well as efficiency benefits arising from coordinated conduct, must be weighed against each other to determine whether a particular conduct has an anti-competitive effect or the requirements for exemption under Article 101(3) TFEU are satisfied. In such unclear legal situations, excessive sanctions can make a firm shy away from particular conduct that is, in fact, permitted. Such a consequence is invidious: on the market, innovation, progress and creativity for the general well-being depend to a large extent on the fact that the players use their legal freedom to experiment and mutually learn from their experiences. Excessive deterrence may restrict this freedom in a way which is detrimental from a social welfare perspective. Certainly, insofar as liability requires proof of fault, courts may apply this requirement to reduce risks of over-deterrence due to ambiguous legal standards. However, a fault requirement may only provide a rather wide-meshed safety net in this regard. For example, according to the adjudication of the German Federal Court of Justice (Bundesgerichtshof), a firm that consciously acts in an area where the borderline between legal and illegal conduct has not yet been drawn by a decision at the highest judicial level, has in general to bear the risk of being negligently liable for an infringement of competition law. ${ }^{22}$ Along the same line of reasoning, Advocate General Kokott argued in Schenker with regard to the imposition of fines:

[An] undertaking $[\ldots]$ acts at its own risk if the legal opinion obtained by it shows that the legal situation is unclear. In that case, the undertaking is at least negligent in accepting that by its market behaviour it infringes the rules of European competition law. ${ }^{23}$

This approach seems reasonable also in view of an effective private enforcement as it leaves incentives for potentially injured parties to bring actions for damages even if the legal situation has not yet been clarified.

Secondly, it should be noted that the concept of a market player that may decide, without further ado, whether or not to infringe competition law, only applies to situations which involve natural persons as the addressees of liability. Article 101 TFEU and the associated liability for damages, however, address the undertaking as an economic entity. ${ }^{24}$ Therefore, the "behaviour-steering" impetus of liability is generally addressed to the company managers who decide about the precaution costs that are spent to prevent infringements of competition law. Such compliance efforts appear, for example, in risk assessments, in training courses for staff members on competition law matters, in the active search for competition law infringements, including the establishment of a whistle-blowing system as well as

\footnotetext{
${ }^{21}$ See supra $\mathrm{n} 13$ and accompanying text.

${ }^{22}$ Bundesgerichshof, 16.12.1986, KZR 36/85, Juris, para 19

${ }^{23}$ Advocate General Kokott, 28.2.2013, Case C-681/11, Schenker \& Co. and others, para 71. The Court did not take up this point but content itself with the statement that "the fact that the undertaking concerned has characterised wrongly in law its conduct upon which the finding of the infringement is based cannot have the effect of exempting it from imposition of a fine in so far as it could not be unaware of the anti-competitive nature of that conduct", ECJ, 18.6.2013, Case C-681/11, Schenker \& Co. and others, para 38.

${ }^{24}$ See Article 1(1) of the Directive on Competition Law Damages.
} 
internal investigations in suspected cases and sanctioning of competition law violations. Aside from that, however, it is essential that the company management clearly signals with all of its actions that it does not seek any economic success at the cost of infringing competition law ("tone from the top"). Against this background, it becomes clear that the image of a "liability addressee" for whom it is clearly apparent that the conduct he intends to follow infringes competition law and who would only need to say "no", does not apply to situations in which, for example, sales people or employees from lower or middle management positions arrange cartels of their own account. The same applies in cases of competition law violations by subsidiaries without or against the will of their parent companies, if the latter are liable for such infringements. ${ }^{25}$ In such situations, an excessive threat of liability can cause company managers and/or parent companies to invest in compliance efforts to a socially undesirable extent or to refrain from carrying out socially desirable activities, such as investing in sectors which are prone to cartels.

These aspects make it clear that those who regard the risks of over-deterrence as irrelevant simply because firms could avoid liability for damages by behaving legally are taking the easy way out. Excessive liability may indeed be too costly ${ }^{26}$ to society as it entails the risk that competition law enforcement in fact disturbs rather than ensures functioning markets. Liability for infringing explicit standards of conduct, such as the ban on cartels, should therefore be adjusted so as to avoid risks of systematic over-deterrence.

Risk of systematic under-deterrence due to deadweight loss triggered by umbrella pricing

Umbrella pricing results in allocative inefficiencies, i.e. it increases the deadweight loss caused by a cartel. Deadweight loss manifests itself as an individual loss for the (potential) transaction partners who have to abandon the products of the firms not party to a cartel due to the latter increasing their prices as a result of the cartel. Optimal deterrence would require that cartel members have to expect to have to compensate for such individual losses as they represent a part of the social welfare loss induced by the cartel.

However, in the case of transactions that were not carried out due to a cartel overcharge, it seems overwhelmingly problematic to identify the individual disadvantaged market participants and to quantify their individual losses. For those market participants who operate in an entrepreneurial manner, deadweight loss takes the form of lost profits. For ultimate consumers who may not purchase the desired product as a result of the excessive price caused by the cartel or who must replace it with a substitute which is less preferred, it manifests itself in a deficit of individual appreciation. It is usually difficult to quantify disadvantages in the form of lost profits because it requires statements about quantities sold at hypothetical market prices. Where the deficit of individual appreciation for endconsumers is concerned, such quantification seems altogether speculative.

If these social damages which accompany umbrella pricing cannot be liquidated in reality, there is a risk that the deterrent effect of liability will be systematically too small. Indeed, this risk must not be neglected. In particular, this risk is not already compensated by the fact that infringements of

\footnotetext{
${ }^{25}$ See ECJ, 10.9.2009, Case C-97/08 P Akzo Nobel [2009] ECR I-8237, paras 54-63, in particular paras 58-9: "It is clear from settled case-law that the conduct of a subsidiary may be imputed to the parent company in particular where, although having a separate legal personality, that subsidiary does not decide independently upon its own conduct on the market, but carries out, in all material respects, the instructions given to it by the parent company [...] having regard in particular to the economic, organisational and legal links between those two legal entities [...]. That is the case because, in such a situation, the parent company and its subsidiary form a single economic unit and therefore form a single undertaking $[\ldots]$. Thus, the fact that a parent company and its subsidiary constitute a single undertaking within the meaning of Article 81 EC [now 101 TFEU] enables the Commission to address a decision imposing fines to the parent company, without having to establish the personal involvement of the latter in the infringement."

${ }^{26}$ But cf. Advocate General Kokott, supra n 19, para 66: “[...] functioning markets characterised by undistorted competition are in themselves an asset beyond all cost-benefit considerations."
} 
competition law would lead to liability for mere redistribution losses anyway (that is, independently from liability for losses resulting from umbrella pricing). This is because de facto only the cartel overcharge but not the deadweight loss can actually be liquidated.

Thus, in order to safeguard an effective deterrence by liability for competition law violations there are indeed good reasons to support damages for losses resulting from umbrella pricing as a "second best" solution.

\section{Weighing up the opposing risks of malfunction and their controllability}

In view of the ambivalence identified above, one has to weigh up whether one rather wishes to rely on damages for losses resulting from umbrella pricing in order to fill the deterrence gap caused by deadweight loss resulting from umbrella pricing, and thereby readily accepts the risk of overdeterrence entailed in such liability, or whether one wishes to avoid such risk and rely on other instruments to make up for the risk of under-deterrence instead.

Those who wish to curtail the risk of under-deterrence, without letting cartel members be liable for umbrella pricing, could either rely on public enforcement by imposition of fines for this purpose or increase the expectation value of the sanction by granting exemplary or punitive damages in excess of mere compensation to the buyers of the cartel. ${ }^{27}$ In contrast, awarding damages for losses resulting from umbrella pricing has the advantage of being linked, albeit loosely, to the deadweight loss. Of course, the amount of loss resulting from umbrella pricing at the expense of the transaction partners of the undertakings not party to the cartel is no indication for the amount of deadweight loss caused by umbrella pricing. However, it can at least be said that both amounts correlate positively with each other.

If one wishes to assess the risk of over-deterrence entailed in granting damages for losses resulting from umbrella pricing, one can consider, on the one hand, that in many instances cartels will not be discovered anyway and aggrieved parties do not (and cannot) file suits for liability, this not least because they bear the burden, in principle, for setting out and showing evidence for the damage caused by the cartel. On the whole, one may therefore regard the risk of over-deterrence as negligible. On the other hand, the existing sanctions - that is, in particular, fines and liability for damages in favour of the buyers of cartel members - can be structured in such a way that the impending sanction gap caused by umbrella pricing is closed and, consequently, that the risk of over-deterrence actually becomes relevant in cases of liability for losses resulting from umbrella pricing.

Although there may therefore be good arguments in favour of liability for losses resulting from umbrella pricing, it cannot be properly decided in the abstract whether this solution should be preferred. The decisive aspect is how large one assesses, against the background of the respective institutional circumstances, the extent of the opposing risks of malfunction, on the one hand, and the efficiency of the respective instruments which are available for correction in the hands of the courts and public authorities, on the other. At this point it must therefore suffice that the ambivalence of damages for losses resulting from umbrella pricing is identified, taking into account the deterrent effect of liability for damages, as well as the criteria to be deducted from this, which have to be considered, if one weighs up the pros and cons of a liability for losses resulting from umbrella pricing along these lines.

27 This second option is not available where one cannot identify any direct buyer as in the case of collusive price manipulations on secondary markets for securities, H Fleischer and E Bueren, "Cornering zwischen Kapitalmarkt- und Kartellrecht", (2013) Zeitschrift für Wirtschaftsrecht 1253, 1262-3. This may be seen as an indication that price manipulations on capital markets would anyway better be governed exclusively by securities law and not by competition law. 


\section{Burdening the courts with (too) complex calculations and unsubstantiated claims?}

Aside from the risk of excessive deterrence, a further objection against liability for losses resulting from umbrella pricing is that it would unduly burden the civil courts. In this spirit, the U.S. Court of Appeals for the Third Circuit decided that the economic correlation between a cartel-related offence and the price that undertakings not party to the cartel charge their transaction partners was too complex for it to be demonstrated with sufficient certainty for forensic practice:

$[\ldots]$ it cannot readily be said with any degree of economic certitude to what extent, if indeed at all, purchasers from a competitor of the price-fixers have been injured by the illegal overcharge. The outcome of any attempt to ascertain what price the defendants' competitors would have charged had there not been a conspiracy would at the very least be highly conjectural. ${ }^{28}$

In trying to determine umbrella pricing, the court stated further, that such compensation proceedings involving cartels were burdened with questions of excessive economic complexity, just the kind the U.S. Supreme Court had been wanting to avoid ${ }^{29}$ by denying standing to successive buyers of cartel members with the "Illinois Brick" doctrine. ${ }^{30}$ Several courts have followed this argument. ${ }^{31}$

Defining a loss in terms of costs as a result of an umbrella transaction is not fundamentally different, however, from proving such loss on the part of the buyer of a cartel. ${ }^{32}$ The plaintiff has to demonstrate, and to provide evidence of, the price which would hypothetically have established itself on the market without the cartel-related offence. This is why the argument regarding an unduly complex economic correlation cannot generally go against considering the cartel-related detriments suffered by umbrella plaintiffs as being eligible for compensation.

The assessment of losses is also not fundamentally different whether umbrella pricing benefits providers of homogeneous goods (and thus perfect substitutes) or providers of imperfect substitutes. Providing evidence of price increases caused by a cartel while taking into account product differentiations, however, requires more complex considerations and procedures for gathering evidence which are more time-consuming. ${ }^{33}$

Meanwhile, foreseeable difficulties in the furnishing of proof should not be a reason to refrain from private enforcement through liability for damages and - in order to avoid social costs caused by unsuccessful claims - to exclude accountability for losses resulting from umbrella pricing (or to confine them to homogeneous substitutes). This would prematurely take away from potential plaintiffs every incentive to look for new means of evidence and enhanced methods by means of which the requirements for demonstration and for providing evidence can be met. With a view to proving the correlation between competition law infringements on the part of the providers of a product and price distortions for (imperfect) substitutes, this primarily relates to the introduction of econometric evidence into forensic practice. The potential for innovation of private plaintiffs should not be underestimated: especially where such private plaintiffs find themselves in competition with each

\footnotetext{
${ }^{28}$ U.S. Court of Appeals, Third Circuit, 26.3.1979, Mid-West Paper Products Co. v. Continental Group, 596 F.2d 573, 584.

${ }^{29}$ U.S. Court of Appeals, Third Circuit, 26.3.1979, Mid-West Paper Products Co. v. Continental Group, 596 F.2d 573, 585-6.

${ }^{30}$ U.S. Supreme Court, 9.6.1977, Illinois Brick Co. v. Illinois, 431 U.S. 720.

${ }^{31}$ U.S. Court of Appeals, Ninth Circuit, 9.11.1982, In re Coordinated Pretrial Petroleum Products Antitrust Litigation, 691 F.2d 1335, 1340 f.; U.S. District Court, N.D. Illinois, E.D., 4.12.1980, In re Folding Carton Antitrust Litigation, 88 F.R.D. 211, 217-220. U.S. District Court, District of Columbia, 7.7.1999, F.T.C. v. Mylan Laboratories, Inc., 62 F.Supp.2d 25, 39; U.S. District Court, C.D. California, W.D., 18.9.2000, Garabet v. Autonomous Technologies Corp., 116 F.Supp2d 1159, 1167-8.

32 Areeda, Hovenkamp, Blair and Durrance, supra n 3, § 347, 199-200; ABA Section of Antitrust Law, Proving Antitrust Damages: Legal and Economic Issues (Chicago, Ill, American Bar Association, 2nd edn, 2010), 230.

33 ABA Section of Antitrust Law, supra n 32, 230-1; PE Areeda, H Hovenkamp, RD Blair and CP Durrance, supra n 3 , $\S 347,200-201$; Blair and Durrance, supra n 2, 2354.
} 
other, as for example law firms specialised in group claims or associations with a right of action, they have strong incentives to introduce novel means of evidence and methods of proof into forensic practice. $^{34}$

The risk that the courts will be unduly burdened by claims that are not substantiated, and that the costs for this will be imposed on the general public, can be sufficiently curtailed by the burden of presentation and the burden of proof ${ }^{35}$ in connection with rules on who should pay the costs of court proceedings and claims for the reimbursement of expenses in favour of successful parties.

\section{On the weakness of the compensatory function as a rationale governing damages liability}

If no clear result can be deducted from the preventive role of liability in favour or against damages for losses resulting from umbrella pricing, but only an imperative to weigh up opposing risks of malfunction, should the "compensatory function" of liability not tip the scales in favour of cartel members having to make good losses resulting from umbrella pricing? This would conform to the position of Advocate General Kokott in Kone. As was already referred to herein, ${ }^{36}$ the Advocate General resorted to a "compensatory function" of liability to dismiss the objection that damages for losses resulting from umbrella pricing go beyond the disgorgement of cartel-related profits:

A claim for compensation is primarily concerned not with recovering from the injuring party the excess that has accrued to him but with awarding to the injured party reparation for the loss he has suffered as a result of the injuring party's unlawful conduct. It is entirely of a piece with that function to extend the civil liability of cartel members to loss resulting from umbrella pricing. ${ }^{37}$

The obligation to make good losses caused by unlawful conduct can be understood as flowing from an imperative of compensatory justice. In the summary of its case-law on cartel damages, the ECJ in Donau Chemie also explicitly contrasted compensation for damage with deterrence as a basis to legitimate liability: there, the Court began by reiterating the well-known extract from Courage $e^{38}$ pursuant to which liability for damages served "first of all" to enforce the rules of competition of the Union, in order to then add:

Secondly, that right constitutes effective protection against the adverse effects that any infringement of Article 101(1) TFEU is liable to cause to individuals, as it allows persons who have suffered harm due to that infringement to seek full compensation $[\ldots]^{39}$

The potential of liability as a mechanism for law enforcement depends on whether individuals can demand to be compensated for a detriment resulting from a violation of rights. This may create the impression which is being expressed - for example in the extracts quoted from the Opinion of the Advocate General, but not in the decisions of the ECJ on cartel damages - that compensation for damage should be given priority; and this not only on an analytical-conceptual level, ${ }^{40}$ but as a legal

${ }^{34}$ BH Thompson, Jr, "The Continuing Innovation of Citizen Enforcement" (2000) University of Illinois Law Review 185, 188, 206-7; MC Stephenson, "Public Regulation of Private Enforcement: The Case for Expanding the Role of Administrative Agencies" (2005) 91 Virginia Law Review 93, 112-3.

35 F Maier-Rigaud, "Umbrella effects and the ubiquity of damage resulting from competition law violations" (2014) 5 Journal of European Competition Law \& Practice 247, 250.

${ }^{36}$ See supra $\mathrm{n} 19$.

${ }^{37}$ Advocate General Kokott, supra n 19, para 78.

${ }^{38}$ See supra $\mathrm{n} 10$.

${ }^{39}$ ECJ, 6.6.2013, Case C-536/11, Bundeswettbewerbsbehörde v Donau Chemie and others, paras 23-4.

${ }^{40}$ Cf. P Cane, “Using Tort Law to Enforce Environmental Regulations?” (2002) 41 Washburn Law Journal 427, 429: “[...] in tort law, compensation is analytically prior to risk-control in the sense that the focus of a tort claim is harm suffered." 
requirement, with the consequence that "behaviour-steering" objectives can be pursued in an accessory and subordinate manner, at best.

However, granting damages always leads to compensation for losses and the suggestion according to which it is the task of liability for damages to compensate loss is no more than a way to paraphrase its operating mechanism. ${ }^{41}$ As such, this mechanism can neither substantiate that compensation was the intended purpose of damages liability, nor can it offer any normative guideline for its features. A "compensatory principle" can contribute only little to the legal substantiation of the scope of accountability of those who act unlawfully, ${ }^{42}$ as long as one does not add to it further considerations about corrective justice that could be operationalised.

The difficulty in referring to a compensatory function of liability in order, for example, to justify the attribution of a specific part of the damage, can be illustrated excellently with the example of the discussion about losses resulting from umbrella pricing: those who view compensation for damage as a rationale which governs liability frequently and readily assume - as did Advocate General in Kone that this rationale argues in favour of cartel members having to make good losses resulting from umbrella pricing. ${ }^{43}$ This fails to fully grasp the issue because the legal requirement for proximate causation does precisely include the possibility that certain pecuniary losses which are linked to an event giving rise to liability do not have to be compensated. Naturally, Advocate General Kokott also presupposes this when she concedes that it was

[...] perfectly legitimate, for the purposes of examining the existence of a causal link, to lay down criteria which ensure that cartel members are not subject to unlimited liability to provide compensation for any losses, however remote, for which their anti-competitive behaviour may have been the cause in the sense of a 'conditio sine qua non' (also known as an equivalent causal link or a but-for causal link). ${ }^{44}$

A "compensatory function" is just as unsuitable as a normative guideline to define accountability for losses as it can be deduced from the compensating effect of liability that its (primary) function was the compensation for damage. Thus, those who advocate that cartel members should have to be liable for losses resulting from umbrella pricing cannot viably justify their reasoning on the grounds of a compensatory function.

${ }^{41}$ G Wagner, "Schadensersatz - Zwecke, Inhalte, Grenzen“, in E Lorenz (ed), Karlsruher Forum 2006: Schadensersatz Zwecke, Inhalte, Grenzen (Karlsruhe, Versicherungswirtschaft, 2006), 12, characterises this as being worded in a "tautological manner".

42 P Cane, Atiyah's Accidents, Compensation and the Law (Cambridge, Cambridge Univ. Press, 8th edn, 2013), 412, n 11: $[\ldots]$ it makes no sense to say that compensation for death and personal injury is the goal of the tort system because even in theory, tort law only compensates for death and personal injury which comes about in certain ways" (emphasis in the original). G Wagner, in FJ Säcker, R Rixecker and H Oetker (eds), Münchener Kommentar zum Bürgerlichen Gesetzbuch (München, CH Beck, 6th edn, 2013), preface to section 823 para 38: "Ebenso deutlich dürfte allerdings ein, dass sich daraus[, dass Schadensersatzansprüche zum Ausgleich erlittener Nachteile führen,] für die normative Orientierung des Haftungsrechts [...] überhaupt nichts ableiten lässt" (emphasis omitted) ("It should certainly be just as obvious that, for the normative orientation of the law on liability [...], absolutely nothing can be deduced [from the fact that claims for damages lead to a compensation of the detriments suffered])."

${ }^{43}$ It is also commonly argued, following such a pattern of argumentation, that the counterbalancing function of liability for cartel damages spoke in favour of giving standing to indirect purchasers and to attribute the cartel-related detriments they have suffered to cartel members as damages, see for instance Logemann, supra n 12, 351-2.

${ }^{44}$ Advocate General Kokott, supra n 19, para 33, see also para 19. 


\section{Liability for umbrella pricing under EU law}

\section{Allocation of powers under EU law and the principle of institutional balance}

The EU legislature is given authority under Article 103 paragraph 1 TFEU to regulate compensation claims for the purpose of private enforcement of Articles 101 and 102 TFEU. It is true that only questions of public enforcement (lit. b, c and e) and issues on substance in terms of competition law (lit. a and d) are indeed addressed in the examples quoted in Article 103 paragraph 2 TFEU. This provision, however, only lists some illustrative examples ("in particular"). Article 103(1) TFEU provides for a regulatory competence of the Union insofar as an intended measure is "appropriate" in order to give effect to the "principles set out in Articles 101 and 102 [TFEU]". This is consistent with the fact that the European Treaties allocate competences in a functional and final manner, i.e. in a way which is task-oriented and targeted towards a specific aim. ${ }^{45}$ Thus, the internal market competence covered by Article 114 TFEU, for example, permits not only the harmonisation of substantive law, but also the adoption of rules for the enforcement of internal market legislation. ${ }^{46}$ At the same time, the Union legislature is authorised, with each competence granted for a specific subject area or horizontally, to regulate the enforcement of the adopted provisions and, as a general rule, it may decide in this respect at its discretion whether to rely on public or private enforcement for this purpose. The criterion of "appropriateness" specified in Article 103 TFEU can be read as a reference to the principles of subsidiarity and proportionality - which operate in a way that generally restricts competences - of the measures under EU law pursuant to Article 5(3) and (4) TEU. Structuring the liability for damages under EU law must therefore hold the promise of a certain added value in terms of sanctions. The ECJ, however, grants the European legislature a broad political margin of discretion in this respect. Only such measures which already present themselves as obviously unsuitable from an ex ante perspective will not meet the requirements laid down in Article 5(4) TEU. ${ }^{47}$

In view of this allocation of competences to the EU legislature, the European Court of Justice in Kone had good reasons not to follow the request of Advocate General Kokott who had suggested that the ECJ should develop the questions which concerned the "existence of claims to compensation" - and, thus, also compensation of losses resulting from umbrella pricing - directly under Article 101 TFEU. ${ }^{48}$ The Advocate General ${ }^{49}$ suggested applying, in particular, the principles of non-contractual liability of the Union's institutions pursuant to Article 340(2) TFEU as sources of legal reasoning for this purpose, in the context of which the European Court of Justice developed the criterion of "sufficient immediacy" with a view to proximate causation. ${ }^{50}$ In addition, Kokott referred to Article VI.-2:101 of the Draft Common Frame of Reference ${ }^{51}$ and the case-law of the highest courts in the Member States to outline proximate causation. ${ }^{52}$

\footnotetext{
${ }^{45}$ PM Huber, Recht der Europäischen Integration (München, Vahlen, 2nd edn, 2002), 243.

${ }^{46}$ See for example ECJ, 9.8.1994, Case C-359/92 Federal Republic of Germany v Council of the European Union [1994] ECR I-3698, para 37; 6.12.2005, Case C-66/04 United Kingdom v Parliament and Council [2005] ECR I-10553, para 45.

${ }^{47}$ See ECJ, 12.7.2001, Case C-189/01 Jippes and others [2001] ECR I-5689, paras 80-84, in particular at para 83: "Thus, the criterion to be applied is not whether the measure adopted by the legislature was the only one or the best one possible but whether it was manifestly inappropriate."

${ }^{48}$ Advocate General Kokott, supra n 19, paras 21-30, in particular at para 23.

${ }^{49}$ Ibid, para 34.

${ }^{50}$ ECJ, 4.10.1979, Joined cases 64 and 113/76, 167 and 239/78, 27, 28 and 45/79 Dumortier Frères and others v Council of the European Communities [1979] ECR 1979, 3091, para 21.

${ }^{51}$ Advocate General Kokott, supra n 19, para 36 n 25.

52 Ibid, para 38, Advocate General Kokott argues that the fact that the opinion according to which the losses of indirect buyers should also be imputable to cartel members was becoming more widely accepted "recently" spoke in favour of finding proximate causation of loss resulting from umbrella pricing, and relies for this purpose, inter alia, on the case-law of the German Federal Court of Justice (Bundesgerichtshof), 28.6.2011, KZR 75/10, BGHZ 190, 145, ORWI.
} 
This suggestion already stood on uncertain ground, because it was based on quite an idiosyncratic interpretation of the Court's case-law. In Courage, the latter had stated:

However, in the absence of Community rules governing the matter, it is for the domestic legal system of each Member State to designate the courts and tribunals having jurisdiction and to lay down the detailed procedural rules governing actions for safeguarding rights which individuals derive directly from Community law, provided that such rules are not less favourable than those governing similar domestic actions (principle of equivalence) and that they do not render practically impossible or excessively difficult the exercise of rights conferred by Community law (principle of effectiveness). ${ }^{53}$

This wording had led Advocate General Kokott to assume that only "details of application of such claims and the rules for their actual enforcement (i.e. the question of how compensation is to be granted), that is to say, in particular, jurisdiction, procedure, time-limits and the furnishing of proof" are incumbent on the Member States to regulate on a subsidiary basis and in line with the principles of equivalence and effectiveness. In contrast, "the existence of claims to compensation (i.e. the question of whether compensation is to be granted)" - and thus also compensation of losses resulting from umbrella pricing - was directly predetermined by Union law. ${ }^{54}$

However, from the ECJ's judgments in Courage and Manfredi, it could already be gathered that the Court had used the quoted wording and the term "procedural rules" in a broader sense. The Court used this term to include all norms which are relevant to the enforcement of substantive competition law. For example, in Courage, it included under this term a prohibition of unjustified enrichment by stating that it was in principle for the Member States "to ensure that the protection of the rights guaranteed by Community law does not entail the unjust enrichment of those who enjoy them". ${ }^{55}$ In the subsequent judgment in Manfredi, the Court clarified that it was for the national laws (on a subsidiary basis) to set out in more detail the term "causal relationship" between an infringement of competition law and sustained losses. ${ }^{56}$ Thus, it was no surprise that the Court in Kone in contrast to what was suggested by the Advocate General, considered it - as a starting point - a matter for the law of Member States to rule on the proximate causation of losses resulting from umbrella pricing. ${ }^{57}$

This restraint on the part of the ECJ is imperative against the background of the division of powers in the Union and the principle of institutional balance applicable for its protection. Each institution must respect the powers of the other institutions when exercising the competences it has been allocated. The ECJ monitors compliance with this legal principle. ${ }^{58}$ As a Union institution (Article 13(1) TEU) and thus as an element of institutional balance, it must also respect its normative requirements itself. In fact, the Treaties allocate to the Court, pursuant to Article 19(1) sentence 2 TEU, the following task: "[i]t shall ensure that in the interpretation and application of the Treaties the law is observed", and the Court is also authorised to further develop Union law accordingly. But in doing so, the ECJ must respect the primacy of the Union legislature with regard to law-making. The Court must not misunderstand a gap in EU law as an invitation to substitute itself for the Union legislature and to undermine the latter's competences.

\footnotetext{
${ }^{53}$ ECJ, 20.9.2001, Case C-453/99 Courage v Crehan [2001] ECR I-6323, para 29.

${ }^{54}$ Advocate General Kokott, supra n 19, para 23.

${ }^{55}$ ECJ, 20.9.2001, Case C-453/99 Courage v Crehan [2001] ECR I-6323, para 30.

${ }^{56}$ ECJ, 23.7.2006, Joined Cases C-295/04 to 298/04 Manfredi [2006] ECR I-6619, paras 63-4.

${ }^{57}$ Kone, supra n 1, para 24. But cf. G Monti, "Umbrella pricing as a sword" (2014) 21 Maastricht Journal of European and Comparative Law, 464, 473.

${ }^{58}$ ECJ, 17.12.1970, Case 25/70 Einfuhr- und Vorratsstelle für Getreide und Futtermittel v Köster und Berodt \& Co [1970] ECR 1161 paras 8-10.
} 
Advocate General Trstenjak, for example, made this point abundantly clear in her Opinion in Audiolux. Therein she refused, by referring to institutional balance, to advise the Court to postulate a general principle of shareholder equal treatment under EU law on the basis of which, for example, all shareholders would have to be entitled to a share of the so-called control premium in the event of a change of control. ${ }^{59}$ The ECJ eventually followed this recommendation. The Court did not, in fact, rely expressly on the protection of institutional balance for this purpose, unlike the Advocate General. However, it justified its judgment, inter alia, with the consideration that the principle which was being invoked could not be established as a general principle with "constitutional status" because it required "legislative preparation". ${ }^{60}$ This emphasis on the primary law character of the general principles of Union law must be read as a reference to the fact that, in Audiolux, the Court definitely had the protection of institutional balance in mind, for, insofar as the Court were to postulate principles at the level of primary law, such as for example the equal treatment of minority shareholders in the event of a change of control, it would thereby bind the EU legislature. ${ }^{61}$

For this reason, the ECJ is not entitled to develop requirements for and legal consequences of liability for damages against cartels by building directly on Article 101 TFEU. As was already established at the beginning of this chapter, it is the Union legislature which is as a matter of principle competent to do so pursuant to Article 103 TFEU. The suggestion made by Advocate General Kokott would therefore amount to an infringement of institutional balance and the ECJ was therefore correct in not following it.

In particular, the freedom of the Union legislature not to make use of its competence, and to deliberately accept that diverging rules on liability develop in the Member States instead, has to be protected, too. In contrast, in her Opinion in Kone, Advocate General Kokott justified the suggestion of harmonising liability building on Article 101 TFEU by arguing that having divergent provisions in the Union would be in contradiction of the objective of European competition law to create a "level playing field" for undertakings, and that such divergent provisions were, in fact, rather an invitation for "forum shopping". ${ }^{2}$ Indeed, the rules on the jurisdiction of the courts, and in particular the possibility to sue cartel members by joinder before a single court (Article 6 No 1 Brussels I Convention) in conjunction with the right to opt in favour of the lex fori pursuant to Article 6(3)(b) of the Rome II Regulation, can allow plaintiffs to opt for liability laws which are favourable to them.

However, one must not necessarily see a harmonisation of liability for cartel damages as the preferable option for its being developed as an effective instrument for the enforcement of competition law. ${ }^{63}$ For one thing, it may be a good idea to have diverging rules in light of the different institutional contexts. While the courts of some Member States may perhaps routinely use the opportunities offered by loss estimation, or may compensate enforcement deficits by granting exemplary or punitive damages ${ }^{64}$ the courts of other Member States may have some expertise in determining damages with sufficient

\footnotetext{
${ }^{59}$ Advocate General Trstenjak, 30.6.2009, Case C-101/08, Audiolux and others, paras 103-108.

${ }^{60}$ ECJ, 15.10.2009, Case C-101/08, Audiolux and others, ECR 2009 I-9823, para 63.

${ }^{61}$ W Schön, "Allgemeine Grundsätze im Europäischen Gesellschaftsrecht“, in S Grundmann et al (eds), Unternehmen, Markt und Verantwortung, Festschrift für Klaus J. Hopt (Berlin et al, de Gruyter, 2010) 1343, 1354.

${ }^{62}$ Advocate General Kokott, supra n 19, para 29.

${ }^{63}$ With regard to the pros and cons of decentralised regulation generally, see, for example, K Gatsios and P Holmes, "Regulatory competition", in PK Newman (ed), The New Palgrave Dictionary of Economics and the Law, vol 3 (London, Macmillan, 1998), 271, 273-275; S Woolcock, "Competition among rules in the Single European Market", in W McCahery, J Bratton, S Picciotto and C Scott (eds), International Regulatory Competition and Coordination (Oxford, Clarendon Press, 1996), 289, 298-301.

${ }^{64}$ An option which, however, has now been rule out by the EU legislature, see Art. 3(3) Directive 2014/104/EU of the European Parliament and of the Council of 26 November 2014 on certain rules governing actions for damages under national law for infringement of the competition law provisions of the Member States and of the European Union, OJ 2014, L 349/1.
} 
precision by using econometric expert opinions, despite complex causal connections. Besides, if one endorses a differentiated development of liability rules, this opens an array of parallel experimentation which allows for mutual observation and learning from respective experiences. For this purpose, one can consider it a catalyst when parties injured by a cartel have some degree of freedom regarding the choice of the place of trial, and thereby the applicable liability laws, in the case of cross-border cartels. Ultimately, there is also an inherent risk of "petrification" in (premature) harmonisation, if one bears in mind that complex political compromises typically underlie law-making at the EU level, e.g. "package" deals made with a view to the multiple and varied interests which exist between and within the institutions of the Union.

For these reasons, one may regard it as preferable - at least for the time being - to refrain from establishing a uniform solution across the Union with respect to particular issues about liability for cartel damages (such as, for example, liability for losses resulting from umbrella pricing). At any rate, especially the question of whether the Union should make use of a potential competence to harmonise the law should be answered by the legislative institutions of the Union which, on the one hand, have democratic legitimacy to do so and, and on the other hand bear political responsibility in this regard. ${ }^{65}$ The ECJ therefore did well in Kone, on the one hand, as it did not make use of the competence to answer individual questions of liability for damages by establishing harmonised rules on cartel damages building directly on Article 101 TFEU. On the other hand, however, as we will argue hereafter, the Court reached virtually the same undesirable effect by overstretching the principle of effectiveness.

\section{Liability for umbrella effects as a discretionary decision of the EU legislature and, on a subsidiary basis, of the Member States}

As the Directive on Competition Law Damages was only adopted in November 2014, the Court in its Kone judgement of 5 June 2014 could still readily hold onto the wording as it was already established in Courage, according to which a pertinent Union regulation was lacking, and infer from this that the question as to the necessary causal connection between a violation of Article 101 TFEU and a loss eligible for compensation was governed by national laws, which in this respect had to observe the principles of equivalence and effectiveness. ${ }^{66}$

In the Directive, the issue of causality has been partly addressed, namely by Article 14 clarifying that indirect buyers are eligible for claims and that, in part, there is also a rebuttable presumption in their favour for a passing on of the loss. In contrast, there are no provisions on the question of proximate causation in the case of losses resulting from umbrella pricing. This issue is only touched upon implicitly when addressing the issue of privilege for leniency applicants. Article 11(4) stipulates that undertakings which have been awarded immunity are jointly and severally liable only "to its direct or indirect buyers or providers" (Article 11(4)(a)) - which excludes inter alia liability for umbrella effects - and "to other injured parties only were full compensation cannot be obtained from the other undertakings that were involved in the same infringement of competition law" (Article 11(4)(b)).

Since therefore the EU legislature, through the Directive on Competition Law Damages, has not addressed the issue of liability of umbrella effects, the latter continues to be governed by national law as a starting point - which, in turn, is bound by the principles of equivalence and effectiveness (Article 4(3) TEU). Subsequently, the question as to whether, under national law, the principle of effective enforcement of Article 101 TFEU requires cartel members to be held liable - or prohibits them from being held liable - for losses resulting from umbrella pricing must therefore be looked into.

\footnotetext{
${ }^{65}$ See Monti, supra n 57, 470: “[...] it is not clear on what basis the Court believes that ad hoc, incremental harmonization of liability rules will somehow minimize the risk of forum shopping or unequal treatment."

${ }^{66}$ Kone, supra n 1 , para 24.
} 
The principle of effectiveness does not require liability for umbrella effects

Since the leading judgment in Commission v Greece, the ECJ requires Member States, in accordance with the principle of effectiveness, to sanction violations of Union law in an "effective, proportionate and dissuasive" manner. ${ }^{67}$ This attributive triad became a regular phrase in the sanction rhetoric of the Court. ${ }^{68}$ As we have seen, the Court committed itself in Courage to the statement that an effective enforcement of EU competition law required private enforcement by means of liability for damages. Member States are therefore not at liberty to decide whether they provide liability for damages for infringements of EU competition law. Moreover, the principle of effectiveness also marks the framework for the requirements and legal consequences of liability under Union law. The terms "proportionality" and "dissuasion", as defining elements of this principle, suggest that the risks of systematic over-deterrence or under-deterrence, respectively, can guide the application of the principle of effective sanctions under Union law. It is up to the Member States to structure liability in such a way that it actually has a deterrent effect, but without thereby allowing for excessive risks of liability.

A limited judicial review is sufficient in the view of the ECJ when applying this benchmark. Based on the principle of effectiveness, EU law should only provide for positive requirements of liability for damages insofar as its role as a mechanism for the enforcement of competition law would be rendered "practically impossible or excessively difficult" by any other national solution. ${ }^{69}$

This qualified judicial review, as well as a certain accompanying restraint when invoking the principle of effectiveness in particular, are necessary in order to safeguard institutional balance. This is because any statements of the ECJ in this regard will ultimately also bind the EU legislature. If the Court were to decide, for example, that the exclusion of liability for losses resulting from umbrella pricing falls below the necessary minimum liability for the required sanctioning effect, it would thereby restrict, at the same time, the freedom of the Union legislature to formulate the law in exercising its competence under Article 103 TFEU. In this case, it would also be impermissible for the legislature not to provide for any liability for losses resulting from umbrella pricing or to refrain from having this particular issue harmonised throughout the Union. The fact that the legislature passing secondary legislation is thus bound follows from the hierarchy of norms: if the legal position to be protected under Union law is grounded in primary law, as is the case with Articles 101 and 102 TFEU, then the requirements for its enforcement, which follow from the principle of effectiveness, also have the character of primary law. $^{70}$

The fact that the legislature passing secondary legislation is bound by the principle of effectiveness is illustrated, for example, by the fact that the Court uses Article 4(3) TEU as a yardstick for the interpretation of secondary legislation. ${ }^{71}$ For example, the ECJ delivered a judgement in "VEBIC" according to which Article 35 Regulation 1/2003 on the protection of the "practical effectiveness of Articles 101 TFEU and 102 TFEU" had to be interpreted in such a way that national competition authorities must be authorised to participate in judicial proceedings which concern decisions they have

\footnotetext{
${ }^{67}$ ECJ, 21.9.1989, Case 68/88 Commission v Greece [1989] ECR 2965, 2985, para 24.

${ }^{68}$ ECJ, 10.7.1990, Case C-326/88 Hansen [1990] ECR I-2911, para 17; 8.7.1999, Case C-186/98 Nunes [1999] ECR I-4883, para 14; 7.12.2000, Case C-213/99, de Andrade [2000] ECR 2000, I-11083, para 19; 16.10.2003, Case C-91/02 Hannl+Hofstetter [2003] ECR I-12077, paras 17, 22.

${ }^{69}$ ECJ, 20.9.2001, Case C-453/99 Courage v Crehan [2001] ECR I-6323, para 29.

${ }^{70}$ W Wurmnest and C Heinze, "General Principles of Tort Law in the Jurisprudence of the European Court of Justice", in R Schulze (ed), Compensation of Private Losses (München, Sellier European Law Publishers, 2011), 39, 45-6.

${ }^{71}$ A von Bogdandy and S Schill, in E Grabitz, M Hilf and M Nettesheim (eds), Das Recht der Europäischen Union (München, C H Beck 2013), Article 4 EUV para 65.
} 
delivered and that the national competition authorities must not be allowed to systematically ignore these procedural rights. ${ }^{72}$

Given the restricted judicial review dictated by primary law when applying the principle of effectiveness, the question has to be asked before postulating a positive requirement for liability for damages: is it intended to actually deny the EU legislature and/or Member States any diverging solution? In view of the eligibility of losses resulting from umbrella pricing for compensation, this question must be answered in the negative. Even though there are good reasons in favour of holding cartel members liable for losses resulting from umbrella pricing, such liability still remains ambiguous given the opposing risks of over-deterrence and under-deterrence. Those who decide on this issue should measure the extent of these risks of malfunction and the efficiency of the control mechanisms available to the authorities and the courts to moderate such risks. ${ }^{73}$ With a view to the respective institutional framework, such a weighing exercise may result in a finding that not to provide compensation for losses resulting from umbrella pricing is an appropriate solution. Any decision on this point should therefore be taken at the discretion of the legislature passing secondary legislation and, on a subsidiary basis, at the discretion of national law.

By deciding in Kone that national law was generally not allowed to exclude damages for losses resulting from umbrella pricing, the ECJ has overstretched the principle of effectiveness. The Court has, without apparent reason, cemented an individual legal question concerning the scope of liability for damages at primary law level and has thereby restricted the competence of the EU legislature arising from Article 103 TFEU, thereby violating the institutional balance.

\section{Liability for umbrella pricing and incentives to apply for leniency}

The obligation of cartel members to pay compensation may reduce their incentives to make use of leniency programmes. Overall, such an obligation may therefore take effect in a way that encourages collusion. ${ }^{74}$ Against this background, the defendants in Kone argued that no liability for losses resulting from umbrella pricing should be imposed in light of the principle of effectiveness. The ECJ rejected this by pointing out, in particular, that the Commission Notice on immunity from fines and reduction of fines in cartel cases ${ }^{75}$ did not have the status of provisions of law and was not binding on Member States. ${ }^{76}$ This consideration fails to fully grasp the issue: ${ }^{77}$ the fact that Member States are not legally bound by the leniency programme under Union law cannot provide any reasons for why the Court was not allowed to take into account the fact that the enforcement of competition law could be altogether weakened for the interpretation of the Union-law principle of effectiveness. An interpretation and application of the law with an eye on the consequences rarely suggests itself as clearly as in the case of the principle of effective enforcement.

Nonetheless, the conclusion reached by the Court is convincing. Firstly, it is evident that the risk that leniency programmes will be weakened is not a problem specific to the issue of damages for losses resulting from umbrella pricing. At best, one could argue more generally that the more extensive the liability imposed, the more it weakens the incentives to cooperate with cartel authorities. It would

\footnotetext{
${ }^{72}$ ECJ, 7.12.2010, Case C-439/08 VEBIC [2010] ECR I-12471, para 64; see also General Court, 29.3.2012, Case T-336/07 Telefónica paras 309-314.

${ }^{73}$ See supra Section C.1.(d).

74 See, e.g., F Silbye, A note on antitrust damages and leniency programs, (2012) 33 European Journal of Law and Economics 691-699.

75 OJ 2006, C 298, p 17.

${ }^{76}$ Kone, supra $\mathrm{n} 1$, para 36.

77 N Dunne, "It never rains but it pours? Liability for 'umbrella effects' under EU competition law in Kone" (2014) 51 Common Market Law Review 1813, 1823-1825.
} 
certainly appear arbitrary if this consideration were to prevail in favour of leniency applicants especially with regard to the proximate causation of losses resulting from umbrella pricing. It would seem even more incoherent to exclude proximate causation for losses resulting from umbrella pricing in general for the protection of leniency programmes, and thus also for the benefit of cartel members that have not cooperated with the authorities. ${ }^{78}$

Even more fundamentally, it must be borne in mind here that the Court had good reasons to impose a certain restraint on itself in the application of the principle of effectiveness and to regard it as being violated only if a national regulation would render the protection of a market player affected by a cartel and/or the effective enforcement of prohibition of cartels "practically impossible or excessively difficult". ${ }^{79}$ However, the notion that it was especially the eligibility of losses resulting from umbrella pricing for compensation that would weaken the enforcement of competition law in an evident and decisive way was not brought forward by any party and would also seem quite absurd. The question of whether, and how, cartel members that cooperated with the authorities, and that will therefore be exempted (at least partially) from fines, are to also enjoy legal privileges with regard to liability, therefore remains subject to secondary legislation. ${ }^{80}$

\section{Market definition does not limit liability for losses resulting from umbrella pricing}

Cartels can also lead to considerable umbrella effects beyond market boundaries, as they are typically defined for the application of (substantive) competition law. ${ }^{81}$ This raises the following question: if the infringement of competition law requires the definition of a relevant market, should this also, at the same time, amount to a legal limitation for the proximate causation of losses resulting from umbrella pricing? Does liability for cartel damages require that an umbrella transaction must be allocatable to the same market as the one which was considered to be relevant for the determination of a violation of Article 101 TFEU? ${ }^{82}$

The answer to this question must tie in with the function of market definition from a competition law perspective. Whether or not collusive conduct is prohibited under Article 101 TFEU may depend on its actual impact on the market and on the effectiveness of competition. Such impact is mostly relevant when it has to be established that particular conduct has the effect of (appreciably) restricting competition. Market definition is also relevant, for example, for an exemption pursuant to Article 101(3) TFEU, which depends on whether competition is excluded for a substantial proportion of the goods concerned through restrictive coordination. In order to analyse and assess whether competition is actually restricted through coordinated conduct, the first step is usually to define the relevant market. On this basis, the ECJ will find that there is a restrictive effect on competition if conditions of competition arise which do not correspond to the normal conditions of this market with regard to the type of products, the importance and the number of undertakings involved, as well as the extent of the market which is being considered. ${ }^{83}$ In relation to the defined market, one must ask: does the agreement or concerted practice restrict the product choice with regard to price, quantity or quality?

\footnotetext{
${ }^{78}$ Significantly, the argument about not providing compensation for losses resulting from umbrella pricing in order to protect leniency programmes was submitted by Kone and Otis, that is two cartel members that had made no application under the Leniency Notice, Kone, supra n 1, paras 7 and 36.

${ }^{79}$ See supra $\mathrm{n} 69$.

${ }^{80}$ See Article 11(4) and (5) Directive on Competition Law Damages.

${ }^{81}$ Inderst, Maier-Rigaud and Schwalbe, supra n 2, 739.

${ }^{82}$ See Logemann, supra n 12, 241-243, and Fuchs, supra, n 19, 170 and 172, who are in favour of assuming proximate causation of losses resulting from umbrella pricing across markets; but see for the contrary view FW Bulst, "Schadensersatzansprüche der Marktgegenseite im Kartellrecht" (Baden-Baden, Nomos and C H Beck, 2006), 281.

${ }^{83}$ ECJ, 28.5.1998, Case C-7/95 P Deere [1998] ECR I-3111 para 87.
} 
Does it act as a barrier to potential competitors to access the market and does it thereby restrict consumer choice?

If this analysis shows that there is a restrictive effect on competition, and if the conduct on the market must therefore be assessed as being contrary to competition law, it does not follow from this, however, that restrictive effects on competition have to be excluded from the scope of protection of the ban on cartels for protagonists outside the market that was being analysed. This would be a misconception of the normative function of market definition and would assign it a legal relevance which it does not have. In the case of Article 101 TFEU, market definition constitutes a first step - which is not mandatory ${ }^{84}$ - in a multi-stage process by which it is intended to assess the anti-competitive potential of an agreement or concerted practice in an efficient way. ${ }^{85}$ For this purpose, an area is defined in which a coordinating conduct is expected to have certain consequences which are regarded as decisive for the question of whether or not this conduct must be prohibited due to its anti-competitive effect. If at this point the impact analysis focuses on a defined market, this excludes, for practical reasons, a closer examination of possible adverse effects which cannot conceivably tip the scales for the assessment from a competition law point of view. However, this does not mean that restrictive effects on competition outside the defined market will thereby be excluded from the scope of protection of Article 101 TFEU. Umbrella effects on substitutes which result from an infringement of Article 101 TFEU can, therefore, also be considered proximate losses in cases where these consequences were not decisive for the verdict of a competition law violation in light of the market definition established earlier in the process as an element of the offence.

The definition of the relevant market under Article 101 TFEU does not, therefore, set any legal boundaries for finding proximate causation of losses resulting from umbrella pricing. Whatever route the legislature passing secondary legislation, or the national legal systems, may choose, in principle, with regard to damages for loss resulting from umbrella pricing: buyers of undertakings not party to a cartel are in any case not prevented from bringing an action for loss resulting from umbrella pricing, because their supplier operates outside the market boundaries which were set for the application of Article 101 TFEU. Insofar as the EU legislature or the national legal systems (which are competent on a subsidiary basis) envisage liability for loss resulting from umbrella pricing, anyone who is in demand of a (purported) substitute is therefore free, in principle, to demonstrate that it has suffered a loss - and to provide evidence of such loss - as a result of a price umbrella which was opened by means of a violation of competition law.

\section{On the implementation of Kone: "reasonable foreseeability" and beyond}

The ECJ prohibits Member States from excluding compensation for loss resulting from umbrella pricing "categorically and regardless of the particular circumstances of the case". ${ }^{86}$ On the basis of this

${ }^{84}$ General Court, 6.7.2000, Case T-62/98 Volkswagen [2000] ECR II-2707, paras 230-1: "As regards the scope of the Commission's obligation to define the relevant market before finding an infringement of the Community competition rules, the Court points out that the approach to defining the relevant market differs according to whether Article 85 [now Article 101 TFEU] or Article 86 [now Article 102 TFEU] [...] of the Treaty is to be applied. For the purposes of Article 86 , the proper definition of the relevant market is a necessary precondition for any judgment as to allegedly anticompetitive behavior [...]. On the other hand, for the purposes of applying Article 85, the reason for defining the relevant market, if at all, is to determine whether the agreement [...] at issue is liable to affect trade between Member States and has as its object or effect the prevention, restriction or distortion of competition [...]. As has already been held in the context of the first plea [...] the Commission duly proved in the decision that the applicant committed an infringement whose object was to restrict competition within the common market and which was by its nature liable to affect trade between Member States. [...] Consequently, the application of Article 85 of the Treaty by the Commission did not require, in this case, that it first define the geographic market."

85 J Haucap, “Abgrenzung des relevanten Marktes - Heilige Kuh oder effizientes Arbeitspferd?“, (2012) Wirtschaft und Wettbewerb 3.

${ }^{86}$ Kone, supra n 1, para 33. 
opinion, umbrella plaintiffs must have a right to sue, and causation between a violation of competition law and a loss resulting from umbrella pricing may also not be generally denied. For all intents and purposes, this answered the question referred by the Oberste Gerichtshof. The ECJ then substantiated an option not to let cartel members be held liable for loss resulting from umbrella pricing on a case-bycase basis. The Court stated that liability required that

$[\ldots]$ it is established that the cartel at issue was, in the circumstances of the case and, in particular, the specific aspects of the relevant market, liable to have the effect of umbrella pricing being applied by third parties acting independently, and that those circumstances and specific aspects could not be ignored by the members of that cartel. ${ }^{87}$

Therefore, according to the Court, liability may depend on the fact that the possibility of an umbrella effect was foreseeable from the point of view of the cartel members. As this requirement has been established by the ECJ, it will be (if necessary) up to the Court to set out this criterion in more detail. However, it seems difficult to imagine a situation in which a cartel member will be able to demonstrate and convince a court that it could not have foreseen the mere possibility of a loss resulting from umbrella pricing. It is therefore not likely that such exceptional non-eligibility of loss resulting from umbrella pricing for compensation will gain significant practical relevance.

The test for the attributability of a particular category of damage seems to be inspired by the criterion of "reasonable foreseeability", which traditionally limits proximate causation in common law jurisdictions. ${ }^{88}$ Under English law, this requirement complements the but-for test: a loss is to be considered "too remote" if, by its very nature, it could not be foreseen by a reasonable person ${ }^{89}$ In jurisdictions such as the English legal system, which already make the compensation of specific categories of loss depend on their foreseeability from the point of view of the wrongdoer, it seems appropriate to use this test to implement the findings of the Court in Kone. However, in Member States jurisdictions which do not provide for such a doctrine, one must look for a functional equivalent. ${ }^{90}$ German law offers some material to illustrate this point.

The draftsmen of the German Civil Code (Bürgerliches Gesetzbuch) deliberately abstained from introducing the criterion of "reasonable foreseeability" into the Code. With a view to contractual liability for damages, ${ }^{91}$ a functional equivalent was seen in the duty to warn pursuant to section 254 (2) sentence 1 of the German Civil Code. According to this provision, the party entitled to damages must point out the risk of exceptionally high losses which cannot be foreseen by the obliged party and therefore, a fortiori, ${ }^{92}$ it has to warn the obliged party if the latter is not aware at all that its conduct could lead to a specific kind of loss. In accordance with the common law rule of

${ }^{87}$ Kone, supra n 1, para 34.

${ }^{88}$ In fact, this is a straightforward textbook example of a legal transplant: originating from France in the late 18th century, the rule was adopted in the United States and thus found its way to England and to the judges of Hadley $v$ Baxendale [1854] 9 Ex341; 156 ER 145, see F Faust, "Comparative Law and Economic Analysis of Law", in M Reimann and R Zimmermann (eds), The Oxford Handbook of Comparative Law (Oxford, Oxford University Press, 2006), 837, 852.

${ }^{89}$ Overseas Tankship (UK) Ltd v Morts Dock \& Engineering Co (The Wagon Mound) [1961] AC 388, 422-3: "For it does not seem consonant with current ideal of justice or morality that, for an act of negligence, however slight or venial, which results in some trivial foreseeable damage, the actor should be liable for all consequences, however unforeseeable and however grave, so long as they can be said to be 'direct'. It is a principle of civil liability [...] that a man must be considered to be responsible for the probable consequences of his act." On the status of the "foreseeability" doctrine in Englisch tort law, see S Deakin, A Johnston and B Markesinis, "Markesinis and Deakin's Tort Law" (Oxford, Clarendon Press, 7th edn, 2013), 247-255.

${ }^{90}$ For a comparative law overview, see W van Gerven, J Lever and P Larouche, "Tort Law" (Oxford and Portland, Oregon, Hart Publishing, 2000), 452-457.

${ }^{91}$ Under English law, the rule on foreseeability applies to contractual as well as tortious liability, but is applied more restrictively in the former case, Deakin, Johnston and Markesinis, supra n 89, 254.

92 T Ackermann, "Der Schutz des negativen Interesses“ (Tübingen, Mohr Siebeck, 2007), 339. 
foreseeability, this duty to warn is capable of resolving the issue of asymmetrical information by limiting liability. If the party (potentially) obliged to pay damages is not aware of the loss potential of its counterpart, the duty to warn prevents the former from making inefficient efforts to obtain relevant information or from generally presuming a loss potential which is too high. ${ }^{93}$ However, this is not well suited to the scenario of liability of cartel members for loss resulting from umbrella pricing: on the one hand, what is lacking here is the information asymmetry in favour of the (potential) injured party presumed in section 254 (2) sentence 1 of the German Civil Code. On the other hand, foreseeability under this rule is applied from the perspective of the injured party, contrary to the requirement stipulated by the ECJ. ${ }^{94}$

It would therefore seem to be appropriate under German law for the implementation of Kone to make use of the requirement that only losses that have been caused adequately must be compensated. Similarly to the "reasonable foreseeability" concept, the criterion of adequacy is based on an assessment of likelihood. Liability is excluded if the event which creates the loss only led to the loss incurred under unique and completely exceptional circumstances. ${ }^{95}$ The decisive aspect in this regard is the possibility of becoming aware of the loss on the part of an objective observer who is in the position of the wrongdoer, which corresponds to the perspective required by the ECJ. ${ }^{96}$ Thus, the exceptional non-eligibility of umbrella pricing losses for compensation must be implemented in accordance with and in the light of the judgment in Kone by construing the criterion of adequate causation accordingly.

\section{Conclusion}

1. From the perspective of effective deterrence, liability for losses resulting from umbrella pricing is to be appraised in an ambivalent way: on the one hand, it creates risks of systematic overdeterrence. This is, in particular, not prevented by the fact that competition law sets explicit standards of conduct. On the other hand, losses resulting from umbrella pricing leads to deadweight losses which at least in practice cannot be realised. In order to reduce the risk of resulting systematic under-deterrence, awarding compensation for losses resulting from umbrella pricing could be recommended as a "second-best" solution.

2. The decisive factor regarding cartel members' liability for umbrella effects should therefore be whether one rather considers the risk of over-deterrence entailed in compensation or the looming risk of under-deterrence in case of non-compensation as acceptable. Those who wish to counterbalance the latter without awarding compensation for umbrella effects can either rely on a complementary public enforcement by means of fines or grant claims for liability for damages in excess of mere compensation (exemplary or punitive damages) to the parties which

\footnotetext{
${ }^{93}$ Faust, supra n 88, 854.

94 This results in a major difference between the "reasonable-foreseeability" doctrine, on the one hand, and the duty to warn under section 254(2) sentence 1 BGB, on the other hand: if neither the wrongdoer nor the injured party can foresee the possibility of a loss, the risk of occurrence of the loss is borne by the injured party, in the first case, and by the wrongdoer, in the second case, T Ackermann, supra n 92, 340.

${ }^{95}$ Bundesgerichtshof, 14.10.1971, BGHZ 57, 137, 141.

96 The requirement of fault could also be considered, in principle, as a criterion for implementation, particularly since the benchmarks for fault and adequacy are hardly different from each other, see H Oetker, in FJ Säcker, R Rixecker and $\mathrm{H}$ Oetker (eds), Münchener Kommentar zum Bürgerlichen Gesetzbuch (München, CH Beck, 6th edn, 2012), section 249 paras 107, 111. However, fault under German law is not required in respect of the losses incurred, Bundesgerichtshof, 30.5.1972, BGHZ 59, 30, 39; Wagner, supra n 42, section 823 para 42. This corresponds to Advocate General Kokott's position in Kone supra n 19, para 72: "It is true that, from a subjective point of view, civil liability may depend on whether the cartel members deliberately or negligently infringed the competition rules laid down in the Treaties. It does not, however, depend on whether the members of the cartel also deliberately or negligently caused the loss actually sustained. Such a requirement of fault would be incompatible with the general principles of civil law and would make it excessively difficult to enforce the competition rules."
} 
have been injured directly. Those who seek to make losses resulting from umbrella pricing eligible for compensation must, on the one hand, count on the fact that the courts will use the steering mechanisms they have been granted and will, in particular, measure cartel-related price excesses in an exact manner and, in any case, not too extensively, and that the courts make use of the fault requirement to minimize risks due to unclear competition law standards. On the other hand, they must rely on the fact that no material risk of over-deterrence will remain, in particular because of general enforcement deficits.

3. The fact that the courts could be burdened by calculations for damages which are too complex is not a convincing argument against liability for damages for losses resulting from umbrella pricing. Providing evidence for such damages does not necessarily consume more resources than determining the financial losses of the buyers of a cartel. Besides, incentives for potential plaintiffs to look for more efficient methods to meet the requirements for the demonstration and providing of evidence should not be readily dismissed.

4. One justification for liability for losses resulting from cartels resides in the fact that it compensates disadvantages resulting from unlawful conduct. Such a compensatory function in itself is, however, not suitable for defining the limits of accountability for loss. Since the legal requirement for proximate causation also includes the very possibility not to provide damages for particular financial losses resulting from a violation of competition law, "compensation" cannot serve as a criterion to clarify whether or not cartel members should also provide compensation for losses resulting from umbrella pricing.

5. Pursuant to Article 103 TFEU, the EU legislature has the authority to regulate the substantive prerequisites of liability for damages in the case of infringements of EU competition law. Thus, the principle of institutional balance prevents the ECJ from deducting these prerequisites in detail directly from Article 101 TFEU, thereby undermining the EU legislature's competence.

6. Through its Directive on Competition Law Damages, the EU legislature did not regulate the issue of damages for losses resulting from umbrella pricing (with a minor exception). National law is therefore applicable in this respect. However, the latter must satisfy the Union law principles of equivalence and effectiveness pursuant to Article 4(3) TEU.

7. Positive requirements for liability for damages caused by competition law violations only follow from the principle of effectiveness insofar as every other national solution would render its efficacy as an enforcement mechanism practically impossible or excessively difficult. In particular, this restricted judicial review applies also in order to safeguard institutional balance. This is because statements which the ECJ bases on the principle of effectiveness and, thus, on primary law in the context of Article 101 TFEU, also bind the EU legislature, even though they are addressed to the Member States, and thereby limit the legislature's competence under Article 103 TFEU. Consequently, the principle of effective enforcement of Article 101 TFEU does not make it mandatory to award compensation for losses resulting from umbrella pricing. In view of the opposing risks of systematic over-deterrence and under-deterrence, not providing compensation for losses resulting from umbrella pricing may, in particular, also constitute an appropriate solution. Any decision on this point is within the discretion of the EU legislature passing secondary legislation and, on a subsidiary basis, within the discretion of national law.

8. It would appear far-fetched to assume that it is liability for losses resulting from umbrella pricing, in particular, which could compromise leniency programmes and public enforcement in such a way that the enforcement of EU competition rules could thereby be significantly weakened. Besides, it would be arbitrary to privilege leniency applicants especially in cases of liability for losses resulting from umbrella pricing and even more absurd to exclude proximate causation for losses resulting from umbrella pricing also for such cartel members that do not cooperate with the authorities.

9. Damages for losses resulting from umbrella pricing are not restricted by market boundaries drawn for the application of Article 101 TFEU. For the purpose of market definition resides in 
the definition of an area in which the relevant effects could be expected which ultimately decides how a specific conduct is to be judged from a competition law point of view. This does not constitute an assessment to the effect that the consequences of such conduct which occur beyond the market boundaries cannot fall within the scope of protection of competition law.

10. The ECJ in Kone held that national law (and, consequently, also EU secondary law) is not allowed to categorically exclude damages for losses resulting from umbrella pricing. Such exclusion was only conceivable if the cartel members could not foresee the mere possibility of an umbrella effect. It is not likely that this requirement will gain significant practical relevance. The wording used by the Court suggests that the judges had a criterion in mind which is similar to the reasonable foreseeability criterion known under English law. In Member State jurisdictions which do not provide for such a doctrine, functional equivalents must be applied. German law under which the requirement of adequate causation of losses would ultimately seem to be a suitable doctrine to implement the Court's approach seems to be paradigmatic in this regard.

This paper has been accepted for publication with the European Competition Journal 
